\title{
ГЕНЕЗА ВЧЕНЬ ПРО СПРАВЕДЛИВІСТЬ ЯК СОЦІАЛЬНЕ ЯВИЩЕ
}

\section{ЯКОВЕНКО Микола Миколайович - здобувач кафедри адміністративного права Міжрегіональної академії управління персоналом}

DOI:10.32782/LAW.2019.3.2

\begin{abstract}
В статье исследовань теоретические и прикладнъие наработки относительно происхождения, становления, возникновения и развития учений о справедливости как соииального явления. Рассмотренъ исторический опьлт формирования мнений ученъхх о сушности понятия справедливости. Проанализированъ его роль в судопроизводстве, ито позволило определить основньле положения по применению принципов справедливости 8 правовых отношениях на определенных исторических этапах. Осуществлена систематизация понятия справедливость, въделив основные его составляющие. Проведено сравнение действия этого явления на определенных исторических срезах.

Ключевъе слова: справедливость, генезис, право, общество, исторический анализ, правоприменения.
\end{abstract}

\section{Постановка проблеми}

На початковій стаді розвитку нової інформаційної ери, яка дістала назву «четверта технологічна революція», де штучний інтелект, інформаційні технології та телекомунікації поступово інтегрувалися майже у всі соціальні сфери, з'явились широкі можливості для проведення інформаційних заходів по відношенню до народних мас. I досить часто для привертання уваги політики вдаються до гучних словосполучень типу «Соціальна справедливість», «справедливий розподіл благ», «справедливі вибори», «забезпечення справедливості для кожного громадянина». Тому можна сказати, що в боротьбі за певні соціальні рейтинги, поняття «справедливість» стало ключовим, незважаючи на нівелювання його сенсу та розмивання сутності. Тому виникає питання: невже поняття справедливості, яку досліджують не одну тисячу років мислителі та філософи, є лише інструментом для реалізації політичних, економічних чи інших інтересів.

Отже, залишається не вирішеною проблема інтерпретації цього поняття в контексті сучасного техногенного суспільства, 3 метою встановлення нових форм прояву справедливості.

Аналіз останніх досліджень і публікацій

Розглядаючи справедливість, як інструмент забезпечення загальних соціальних інтересів можна звернутися до праці дослідника С. Кара-Мурзи, який стверджує, що про справедливість починають говорити саме тоді, коли на наших очах відбувається величезна несправедливість, яка прямо або опосередковано стосується всіх або майже всіх [1, с. 34].

Поняття справедливість в усі історичні періоди було різним, тому можна розглядати його як складне явище, що завжди справляло величезний вплив на всю систему суспільних відносин.

На початковому етапі розвитку цивілізації слово «справедливість» увійшло в мову всіх народів, а перші уявлення сформувалися ще в первісному суспільстві.- 


\section{Теорія, історія держави і права, конституційне право}

У різні періоди, особливо це стосується початкових, умови спільного життя людей вимагали встановлення загальної рівності, тому справедливість розглядалась як необхідність виконувати існуючі обряди і звичаї. Детально початковий історичний етап розвитку вчень про справедливість вивчав О. Прокоф'єв, який наголошував на тому, що соціальні зміни в суспільстві призвели до зміни уявлення про справедливість. [2, с. 12].

Також до аналогічних тверджень можна віднести погляди Д. Роулза [3, с. 386].

Вивчаючи стародавню філософію, слід відмітити вчення Конфуція, який висловлювався так: «Справедливо все те, що сприяє зміцненню централізованої влади правлячих верств, зберігає єдиновладдя та зміцнює повагу до старших в соціальній ієрархії» [4]. Таким чином, на перших етапах формування суспільної свідомості осмислення людиною зовнішнього світу визначалося його ставленням до навколишньої природи та відносинами зі своїми одноплемінниками.

Гесіод, один 3 ранніх представників давньогрецької літератури і громадської думки, у своїх творах висловлював судження про справедливість таким чином, що поняття справедливості означало не тільки чесність, але, перш за все відмову від захоплення чужої власності будь-яким шляхом, а метою справедливості вважав таку міру, як взаємна вигода або оптимальний розрахунок в соціальних відносинах. Так, справедливість у Гесіода була нерозривно пов'язана з цінностями вільних хліборобів і мала цілком соціалістичний характер [5, c. 39]. Так само Геракліт Ефеський вважав, що всі позитивні закони, за які народ повинен боротися, випливають зі справедливості $[6$, с. 45$]$.

3 даних визначень можна зробити висновок про те, що тогочасні філософи описують певні характеристики поглядів, які є взаємодоповнюючими. Проте тут можна виділити ряд ознак, які поділяють бачення на дві категорії: розуміння справедливості, як стабільної політичної форми існування суспільства та беззаперечної справедливості, не залежної від інтересів переважної частини суспільства. Відповідна думка може бути підкріплена уявленнями Д. Локка, який також вважав, що справедливість має двояке розуміння. Першим було внутрішнє прагнення до власності, здатність до праці і вимога особистої недоторканності. Іншим можна вважати - встановлення відповідних законів для захисту природних прагнень людини. Загалом, дослідження початкової стадії розвитку генези про справедливість [7], [8], [9], [10] призводить до висновку, що найчастіше між людьми була відсутня згода щодо розуміння справедливості, як єдиного соціального явища.

У подальшому почали з'являтися більш ретельні дослідження. Так, Демокріт першим почав стверджувати, що справедливість не тільки існує, а й є достовірне знання про неї, на перший план висунувши твердження про об'єктивність справедливості. Демокріт стверджував, що справедливість невіддільна від природи та виражає ії сутність. «Справедливість, - говорив він, - це виконання боргу, а несправедливість - відсутність дій щодо виконання цього боргу перед суспільством». [2, с. 159].У продовження розвитку даного твердження Сократ намагався довести існування єдиного і загального поняття справедливості, пов'язуючи його з моральністю і знанням. Характеристики цього явища зводились до розуміння справедливості, як мудрості.

Справедливі вчинки і взагалі всі вчинки, за Сократом, були засновані на чесноті [11, с. 119].

Епікур стверджував, що справедливість є результатом договору, укладеного між людьми, сенс якого - не шкодити один одному і не терпіти шкоди [12]. Досліджуючи його праці, можна виділити, що справедливість Епікура двоїста, вона має природню основу і в той же час визначається людськими відносинами, які зафіксовані в різних угодах соціального порядку.

Подальший розвиток ідея справедливості отримала у юристів Стародавнього Риму. Так, Цицерон вперше обгрунтовував ідею правової справедливості, після чого поняття справедливості почало переміщатися з області філософії в область правової науки [13]. 
Розвиток, вчення про право та справедливість середньовічної епохи починало набирати чітко виражених правових ознак, формуючи юридичний світогляд. Епоха боротьби буржуазії з пануючими феодальними порядками принесла з собою нові моменти не тільки в соціально-практичному застосуванні, але й в теоретичному тлумаченні поняття справедливості. Як стверджував засновник філософії Нового часу Френсіс Бекон: «Справедливість є те, що об'єднує людей і створює підстави для права» [14]. Ф. Бекон прийшов до висновку, що справедливість у взаєминах між людьми повинна грунтуватися на визнані суверенності кожної окремої особистості. Таким чином, поняття природної справедливості знаходило сенс, який був спрямований проти феодальних порядків, що забезпечували інтереси буржуазії.

До яскравих представників суспільнополітичної думки XVII ст. можна віднести Т. Гоббса та Б. Спінози, які обгрунтували вчення про природне право, пов'язавши свої уявлення про справедливість з головним політичним інститутом суспільства державою. Т. Гоббс, створюючи одну 3 перших в Новий час конструкцій державності, стверджував, що держава і справедливість змогли виникнути 3 подоланням людьми природного стану розуміння оптимального співіснування. Гоббс досліджував державу як творіння людини, вважав одним з головних його достоїнств розум, проявлений у справедливості та законах. Він розглядав справедливість як підпорядкування законам, як постійне прагнення вшанувати право [15, с. 261].

Серед французьких мислителів XVIII ст. більш демократичні погляди висловлював Ж. Ж. Руссо, який вважав, що є одна абсолютна справедливість, яка виникає виключно з розуму і здійснюється за допомогою законів [16, с. 127].

Уявлення I. Канта про справедливість будувалися на основі використання такого поняття, як соціальна етика, де головним аспектом у забезпеченні справедливості була свобода у відносинах між людьми. I. Кант вважав, що розвиток усіх талантів лю- дини можливий лише при сформованому правовому та цивільному устрої [17, с. 177].

Переходячи до більш сучасних підходів до розуміння справедливості, можна виділити такий факт, що в даний час у наукових обговореннях справедливість розглядається так або інакше, як образ певного бажаного суспільно-політичного та економічного устрою. Згідно з О. Хеффе, «людська практика в самих різних iï аспектах має бути направлена на розбудову справедливих принципів та тверджень». Такі аспекти німецький дослідник справедливості розуміє, як показник ефективності людського співіснування [18, с. 25]. Тому розуміння справедливості виявляється спочатку вбудованим в контекст відносин, починаючи від побажань до вимог взаємодії суб'єктів співіснування, а потім і до неминучого використання силового примусу.А. В. Прокоф'єв підкреслює навіть, що витоки етики справедливості пов'язані з агресією проти порушників взаємності таких соціальних відносин [2, с. 28-29].

Таким чином, у результаті проведення аналізу розвитку поняття справедливості необхідно зробити висновок, що дана проблема 3 давніх часів була предметом дослідження різних учених та філософів, проте поєднання ідей справедливості, закону, вимог суспільства та держави втілилося в суспільне життя різних країн лише останні часи і почало розглядатися як форма регулювання відносин у суспільстві, його гармонійного розвитку та перспективного зростання.

\section{Постановка завдання}

Дослідити теоретичні та прикладні напрацювання стосовно походження, становлення, виникнення та розвитку вчень про справедливість як соціального явища. Проаналізувати історичний досвід формування думок науковців щодо сутності поняття справедливість. Дати оцінку ролі цього поняття в судочинстві. Систематизувати поняття справедливість, виділивши основні його складові, порівнявши дію цього явища на певних історичних зрізах. 


\section{Теорія, історія держави і права, конституційне право}

\section{Виклад основного матеріалу дослідження}

3 проведеного аналізу розвитку досліджень, які характеризують сутність, правозастосування, юридичне закріплення та загалом, сприйняття поняття справедливість, слід виділити такий факт, що в історичному аспекті справедливість має різне тлумачення. Неоднаковий зміст вкладається в ідею справедливості в античному світі, в середніх роках, i, як результат, сьогодні ми маємо нові виклики сучасності, і не лише нормативно, а й морально, суспільство не підготовлено до їх подолання. Поняття справедливості вбирає в себе не тільки конкретно-історичні обставини, а й інтереси членів суспільства.

Так, у період проведення правових реформ відбувається зростання цінностей справедливості, проте їх роль залишається інструментом для збільшення соціальних рейтингів. Складна ситуація, до якої прийшла наша держава, загострила багато колізій, чим поставила суспільство перед необхідністю здійснити потужний ривок до оновлення держави, змінюючи сучасні форми відродження справжніх цінностей.

Проте, слід зауважити, що в сучасних умовах, якість життя визначається не тільки матеріальним надбанням, а й моральним кліматом та здатністю громадських систем забезпечити побудову взаємин між людьми на основі гуманізму і справедливості.

Враховуючи той факт, правова система в Україні побудована на основі принципу справедливості, а їі роль закріплена майже у всіх важливих нормативних документах держави [19, 20, 21 ...], взаємозв'язок права та моралі розуміється вже як традиційна область юридичних досліджень. Переважно такий взаємозв'язок вивчався загально, проте існують й інші способи аналізу проблеми, наприклад, з'ясування особливостей взаємодії права, з мораллю та окремими етичними категоріями. Так, наприклад, на рівні закону це закріплено в пункті першому ст. 2 Закону України про «Судоустрій і статус суддів», де визначено, що суд забезпечує кожному право на справедливий суд та повагу до інших прав і свобод, гарантованих Конституцією та законами України, а також міжнародними договорами». Право на справедливий суд у такому контексті формується у взаємозв'язку із моральними цінностями, що закріплені як у вітчизняному правовому середовищі, так і в міжнародних правових нормах. Зважаючи на те, що ці дві категорії розглядаються окремо одна від одної, право на справедливий суд є логічним продовженням моральних принципів, що уособлюють у собі засади верховенства права [22]. Також слід звернути увагу на дотримання конституційних принципів справедливості в Кримінальному кодексі, де особа, що вперше вчинила злочин незначної тяжкості, може бути звільненою від кримінальної відповідальності у зв'язку 3 дійовим каяттям (ст. 45 ККУ), у зв'язку 3 примиренням 3 потерпілим, а також відшкодуванням збитків або усуненням заподіяної шкоди (ст. 46 ККУ), за можливості передачі особи на поруки (ст. 47 ККУ). Також особа може бути звільнена від покарання, якщо на час розгляду справи в суді іiі не можна вважати суспільно небезпечною (ч. 4, ст. 74 ККУ) [23].

Зважаючи на широкий спектр розповсюдження, принцип справедливості відіграє важливу роль у разі встановлення прогалин в законодавстві, у такому випадку застосовують не аналогію закону, а аналогію права, i, таким чином він має не розривний зв'язок із принципом верховенства права. Прикладом такого правозастосування можна вважати положення п. 2 ст. 8 Цивільного кодексу України (ЦКУ), де встановлено, що в разі неможливості використати аналогію закону для регулювання цивільних відносин вони регулюються відповідно до загальних засад цивільного законодавства, що і $є$ аналогією права. Підпункт 6 п. 1 ст. 3 ЦКУ до загальних засад цього кодексу також відносить справедливість [24].

Проблема вирішення права на справедливий суд неодноразово вирішувалась у міжнародних судах, правові принципи яких повністю узгоджені 3 принципом справедливості. Так, ст. 6 Конвенції про захист прав людини і основоположних свобод встановлює, що «кожний громадянин має право на справедливий і публічний розгляд його справи впродовж розумного строку не- 
залежним і безстороннім судом» [25]. Проте, дія даного положення реалізується лише в тому випадку, якщо будуть дотримані процедури незалежного та неупередженого судового процесу. Міжнародна судова практика мала такий досвід, коли поряд із принципом справедливості застосовувався принцип формальної рівності. Таке поєднання передбачає однакове ставлення до представників різної статі, расової належності, кольору шкіри, віросповідання, світогляду тощо [26]. До яскравих прихильників такої практики можна віднести Джона Ролза, який вважав, що кожен громадянин повинен мати рівні права незалежно від того, ким він є (мається на увазі соціальний статус). До таких ідей можна віднести рівноправний доступ до посад. Проте, зважаючи на високу моральність, у поєднанні правових принципів «справедливості» та «рівноправності», можна виділи небезпечні шляхи маніпулювання загальною справедливістю, де інструментом маніпуляції виступає саме право. Так, застосовуючи поєднання цих правових принципів, у ЗМІ широко розповсюджується інформація про нормальний розвиток сімейних стосунків між чоловіками, або жінками. На основі поєднання цих принципів в деяких країнах одностатеві шлюби отримали право на всиновлення дітей [27]. Зважаючи на те, що пригнічення представників даної категорії загальна правова концепція ні в якому разі не припускає, в той же час, на основі поєднання справедливості та рівноправності такі громадяни проводять різні заходи, рекламуючи свій стиль життя дітям та підліткам. Результатом такої пропаганди можна вважати сучасні тенденції в моді, коли чоловіче вбрання все більше стає схожим на жіноче [28]. Усе це становить демографічну небезпеку для країни, порушує сімейні традиції i, що найнебезпечніше, підриває християнські цінності, які $\epsilon$ непорушною основою загальної справедливості. Серед судової практики багато прикладів, коли принцип справедливості працює сам проти себе. Таким чином, на сучасному етапі розвитку правничої науки, поєднання принципів справедливості та рівноправності вказує на загрозливий характер.
Звертаючись до принципів міжнародного права, які характеризують стосунки між державами, відповідно до Статуту ООН можна спостерігати принцип загальновизнаної людської цінності, як світового надбання, що підлягає охороні, як особливо важливе благо і стоїть навіть вище за принцип права, що більш наближений до справедливості, як явища суспільних відносин [29]. Тому можна зробити висновок, що справедливість у праві не завжди відображає загальні принципи справедливості. I у зв'язку з тим, що сьогодні в суспільних відносинах закладений інтерес для реалізації основних потреб суб’єктів таких відносин, принцип справедливості може розглядатися, як інструмент досягнення цілей, для окремих громадян та певних груп. А з урахуванням наявності монополій у $3 \mathrm{MI}$, така концепція, з використанням технологій маніпулювання цінностями, поглядами та інтересами громадян, несе найбільшу загрозу для людства. Таким чином, справедливість, на сучасному етапі розвитку суспільства, може розглядатися як норма людських цінностей, що встановлена впливовою часткою людства для забезпечення їх інтересів 3 урахуванням історичних обставин та соціальних умов і може змінюватись у залежності від вподобань соціального середовища, їх цінностей та потреб.

Справедливість загальна, не залежно від побажань або вподобань соціальної більшості, соціальних еліт, держави або наднаціональних структур, завжди була, є, i буде непорушним законом, який встановлений для людства 3 метою регулювання соціальних відносин громадян у всі часи.

\section{Висновки}

На історичному етапі розвитку вчень про походження, становлення та виникнення такого соціального явища, як справедливість, 3 давніх часів і по сьогодні, поки що не склалося єдиної концепції поєднання ідей справедливості, закону, вимог до державотворчих процесів, соціальних інтересів та права.

Генеза вчень про справедливість, у сучасних умовах почала розглядатися як форма регулювання відносин у суспільстві, 


\section{Теорія, історія держави і права, конституційне право}

його гармонійного розвитку та перспективного зростання. Проте, загрозою для справедливості, як норми права, залишається питання його поєднання 3 іншими правовими принципами, оскільки $е$ ймовірність маніпуляції справедливістю, з метою реалізації інтересів окремих осіб або соціальних груп.

Вітчизняне судочинство у своїй основі, базується на принципах справедливості, що виражено в закріпленні цього принципу в основних нормативних документах країни. I хоча норми права мають забезпечувати втілення принципів справедливості в соціальні системи, як загальне явище, правова справедливість може бути знівельована та використана в корисних цілях. Загальна ж справедливість є незмінною, мета якої - оптимальне регулювання соціальних відносин.

\section{Лiтература}

1. Кара-Мурза С. Что такое справедливость // Российская Федерация сегодня. 2009. № 1 .

2. Прокофьев А. В. Справедливость или преодоление человеческой природы // Этическая мысль. М., 2003. С. 23. Вып. 4.

3. Роулз Д. Теория справедливости // Әтическая мысль. М., 1990. С. 230.

4. Yu, Jiyuan (July 2005) The Beginnings of Ethics: Confucius and Socrates // Asian Philosophy 15. Pp.173-89.

5. Иванов В- Г. История этики Древнего мира. СПб., 1997. С. 147.

6. Материалисты Древней Греции. М., 1955.

7. Шохин В. К Философия ценностей и ранняя аксиологическая мысль. М., 2006. C. 103 .

8. Osbom E. The Emergence of Christian Theology. Cambrige, 1993. Р. 115.

9. ХайдеггерМ. Бытие и время. М, 1993. С. 386.

10. Трубецкой С. //. Метафизика в древней Греции. С. 240.

11. Флоренский П. А. Личность Сократа и лицо Сократа // Вопросы философии.М., 2003. - № 8. - С.123-131.

12. Bailey C. The Greek Atomists and Epicurus. - Oxford, 1928.
13. Taylor-Briggs R. Reading between the lines // The Rhetoric of Cicero in Its Medieval and Early Renaissance Commentary Tradition. - Leiden; Boston: Brill, 2006. - P. 101.

14. Ф. Бэкон, Соч. в 2-х тт, т.2-й, Опыт XVI «O безбожии», М., «Мысль», 1972, с. 386.

15. Гоббс Т. Избранные произведения. M., 1956. Т. 1.

16. Длугач Т. Б. Три портрета эпохи Просвещения. Монтескьё. Вольтер. Руссо (от концепции просвещенного абсолютизма к теориям гражданского общества). - М.: Изд-во Института философии РАН (ИФРАН), 2006. - 249 с.

17. И. Кант. Критика чистого разума / (Пер. с нем.; предисл. И. Евлампиева). М.: Эксмо; СПб.:Мидгард, 2007. - 1120 с.

18. Хеффе О. Политика, право, справедливость: Основоположения критической философии права и государства. М., 1994.

19. Конституція України (Відомості Верховної Ради України (ВВР), 1996, № 30, ст. 141), [Електронний ресурс], Режим доступу: https://zakon.rada.gov.ua/laws/ show/254\%D0\%BA/96-\%D0\%B2\%D1\%80.

20. Кодекс Адміністративного судочинства України (Відомості Верховної Ради України (ВВР), 2005, № 35-36, № 37, ст.446), [Електронний ресурс], Режим доступу: https://zakon.rada.gov.ua/laws/show/2747-15.

21. Цивільний Процесуальний кодекс України (Відомості Верховної Ради України (ВВР), 2004, № 40-41, 42, ст.492), [Електронний ресурс], Режим доступу: https://zakon.rada.gov.ua/laws/show/1618-15.

22. Закон України «Про судоустрій i статус суддів» від 07.07.2010 р. (в ред. від 28.04.2012 р.) // Відомості Верховної Ради України (ВВР). - 2010. - № 41-42, № 43,№ $44-45$. - Ст. 529.

23. Кримінальний Кодекс України (Відомості Верховної Ради України (ВВР), 2001, № 25-26, ст.131), [Електронний ресурс], Режим доступу: https://zakon.rada.gov. ua/laws/show/2341-14.

24. Цивільний кодекс України від 16.01.2003 р. (в ред. від 13.03.2012 р.) // Відомості Верховної Ради України (ВВР). 2003. - № 40-44. - Ст. 356. 


\section{АНОТАЦІЯ}

У статті досліджено теоретичні та прикладні напрацювання стосовно походження, становлення, виникнення та розвитку вчень про справедливість як сочіального явища. Розглянуто історичний досвід бормування думок науковиів щодо сутності поняття справедливість. Проаналізовано його роль у судочинстві, щзо дозволило визначити основні положення стосовно застосування приниипів справедливості в правових відносинах на певних історичних етапах. Здійснено систематизацію поняття справедливість, виділивши основні його складові. Проведено порівняння дї иъього явища на певних історичних зрізах.

Ключові слова: справедливість, генеза, право, суспільство, історичний аналіз, правозастосування.

25. Загальна декларація прав людини від 10.12.1948 р. URL: http://zakon3.rada. gov.ua/laws/show/995_015 (дата звернення: 03.05 .2012 р.); Конвенція про захист прав людини і основоположних свобод від 04.11.1050 р. (в ред. від 27.05.2009 р.). URL: http://zakon2.rada.gov.ua/

26. Д. В. Скринька Рівноправності та права народів розпоряджатися своєю долею // Українська дипломатична енциклопедія: У 2-х т./Редкол.:А. В. Губерський (голова) та ін. - К.:Знання України, 2004 - Т.2 $812 \mathrm{c}$.

27. Erstes schwules Ehepaar adoptiert Kind (нем.). Berliner Zeitung (10. Oktober 2016). Дата звернення 2 липня 2016.

28. Вика Дядькина АГБТ-символика в коллекциях модных брендов - есть ли в

\section{SUMMARY}

The article deals with theoretical and applied developments in relation to the origin, formation, emergence and development of the doctrines of justice as a social phenomenon. The historical experience of forming the opinions of scientists about the essence of the notion of justice is considered. His role in the legal process was analyzed, which allowed to define the main provisions concerning the application of the principles of justice in legal relations at certain historical stages. The systematization of the notion of justice is made, highlighting its main components. A comparison of the effect of this phenomenon on certain historical slices has been carried out.

Key words: justice, genesis, law, society, historical analysis, law enforcement.

ней смысл? [Електронний ресурс] /Дядькина Вика// LOFFICIEL. - 2016. - Режим доступу до ресурсу: https://www.lofficielrussia. ru/moda/lgbt-fashion. Дата звернення 2 липня 2016.

29. Декларація про принципи міжнародного права, що стосуються дружніх відносин та співробітництва між державами відповідно до Статуту ООН, Документ 995_569, поточна редакція Прийняття від 24.10.1970, [Електронний ресурс], Режим доступу: https://zakon. rada.gov.ua/laws/show/995_569. 